\title{
Fluid focusing and back-reactions in the uplifted shoulder of the Rhine rift system: a clay mineral study along the Schauenburg Fault zone (Heidelberg, Germany)
}

Received: 19 July 2004 / Accepted: 18 March 2005/Published online: 10 June 2005

(C) Springer-Verlag 2005

\begin{abstract}
A retrograde sequence of fluid-controlled, lowtemperature mineral reactions has been preserved along an east-west striking, dextral-oblique-slip fault in the uplifted Rhine Graben shoulder. This fault (the Schauenburg Fault, near Heidelberg), juxtaposes Permian rhyolite against Carboniferous (Variscan) granite and shows syn- or post-rift displacement of the north-south trending, eastern boundary fault of the rift basin. Both mineral texture and rock fabric indicate that the fault forms a site of high rock permeability and fluid flow, and records the exhumation and fluid-rock history of the rift shoulder since the Mesozoic. The reaction sequence and mineral compositions of the clay minerals within the cataclasite, and adjacent granite and rhyolite lithologies, document progressively decreasing fluid temperatures, with back-reactions of pure $2 \mathrm{M}_{1}$ illite to $1 \mathrm{M}_{\mathrm{d}}$ (R3) illite-smectite, and eventually smectite and kaolinite assemblages. Compositional variations are attributed to Tertiary to Recent fluid flushing of the fault zone associated with rift flank uplift, and with progressive dilution of the electrolyte-rich, acidic to neutral hydrothermal brines by down-flowing electrolyte-poor, meteoric waters.
\end{abstract}

Keywords Clay minerals - Rhine rift system · Faulting $\cdot$ Fluid-rock interaction $\cdot$ Exhumation

A. M. Schleicher $(\square)$

Geologisch-Paläontologisches Institut,

Ruprecht-Karls-Universität INF 234,

69120 Heidelberg, Germany

E-mail: anja.schleicher@urz.uni-heidelberg.de

Tel.: + 49-6221-544832

Fax: + 49-6221-545503

L. N. Warr

Centre de Géochimie de la Surface (CNRS-ULP),

1 rue Blessig, 67084 Strasbourg, France

B. A. van der Pluijm

Department of Geological Sciences,

The University of Michigan,

Ann Arbor, MI 48109, USA

\section{Introduction}

Uplifted rift shoulders play an important role in influencing the regional flow of fluids within intracontinental extensional basins (Person and Garven 1994; Stanislavsky and Gvirtzman 1999). The localized areas of higher topography create a hydro-dynamic gradient that drives waters downward into aquifers within the syn-rift sequence (Abebe 2000; Lampe et al. 2001; Clauser et al. 2002). Our understanding of the regional hydro-dynamic behavior of rift shoulders and their evolution through time has been advanced by modeling fluid flow, taking into account permeability, thermal gradients, topography, crustal stress and fluid chemistry (van Balen and Cloetingh 1993; Bartels et al. 2000; Pribnow and Clauser 2000). An important aspect of such studies is to predict the physical and chemical properties of faults in the uplifting graben shoulders, which have implications for understanding and exploiting water, thermal and mineral resources in sedimentary basins (Carlé 1958; Evans 1990; Sibson 1994; May et al. 1996; Lampe et al. 2001), as well in the safety assessment of underground waste repositories (Gautschi 2000).

The formation of clay minerals in faults have been shown to play a particularly important role in influencing the flow of fluids in sedimentary basins (Knipe 1993). Clay growth affects anisotropy, permeability and porosity as well as fault strength (Morrow et al. 1984; Wintsch et al. 1995; Wibberley 1999; Warr and Cox 2001; Solum et al. 2003). Clay minerals also provide important information concerning fluid composition, temperature and the degree of fluid-rock interaction (Velde 1985; Inoue et al. 2004). However, in contrast to the well studied continuous, prograde clay mineral reactions from smectite to illite-smectite to illitemuscovite within burial diagenetic, low temperature metamorphic and hydrothermal environments (Srodon and Eberl 1984; Hunziker et al. 1986; Dong et al. 1997), the nature of retrograde illitic and smectitic mineral reactions in fault rocks (Zhao et al. 1999; Abad et al. 
2003), and in particular within the uplifted flanks of rift basins, has received much less attention.

In this contribution we examine the nature of fluidrelated clay mineral reactions within faulted crystalline basement rocks along the eastern uplifted flank of the Rhine Graben in western Europe, in the vicinity of Heidelberg, Germany. Based on an X-ray and electron microscopy study of reaction textures, mineral compositions and clay fabrics across the Schauenburg Fault, an $\mathrm{E}-\mathrm{W}$ trending structure lying just $100 \mathrm{~m}$ from the main graben boundary fault, the exhumation and fluid-rock history of the rift flank is addressed. The Rhine Graben provides an excellent region for such a study, because of the young age of the rift system, its well-defined upliftedshoulders, and the availability of water chemistry from various depths in and around the graben system (e.g. Carlé 1975).

\section{The Rhine Graben rift system and its thermal waters}

The Rhine Graben forms the central segment of the European Cenozoic rift system (Fig. 1). It extends over a distance of more than $1,000 \mathrm{~km}$ from the North Sea to the Alpine mountain chain (Illies and Fuchs 1974; Prodehl et al. 1995). Limited by the Rhenish Massif (Frankfurt, Germany) in the north and the Jura Mountains (Basel, Switzerland) in the south, the NNE trending Upper Rhine Graben has a length of about $300 \mathrm{~km}$ and a width of $\sim 30-40 \mathrm{~km}$ (Schumacher 2002). The rift is filled with a thick sequence $(3,000$ $3,400 \mathrm{~m}$ ) of post-Cretaceous sediments (Illies 1968), and the vertical offset between the elevated graben shoulders and the basement within the graben reaches a maximum of $4,500 \mathrm{~m}$. Due to the thermal and flexural uplift of the graben shoulders, which commenced during the early Eocene, various crustal levels have been exhumed along the flanks of the rift system (Laubscher 2001).

A large amount of data is available on the chemistry of sampled waters from various boreholes and thermal waters in the Rhine Graben rift complex and adjacent areas (Carlé 1958; Aquilina et al 1997; Stober and Bucher 2000; Durst and Vuataz 2000). The hot waters $\left(>137^{\circ} \mathrm{C}\right.$ ) collected from the Soultz-sous-Forêts or the Cronenbourg borehole sites in basement granite of the rift basin yielded weakly acidic (pH 4.7-5.2) saline brines containing significant concentrations of $\mathrm{NaCl}$, as well as Li and Sr (Pauwels et al. 1993; Aquilina et al. 1997). Similarly, weak acidic $\mathrm{NaCl}$ brines are reported from the Black Forest crystalline rocks outside of the rift basin to the east (Stober and Bucher 1999). In the Urach 3 borehole, reliable water brines with temperatures of $150^{\circ} \mathrm{C}$ were recovered from depths of 3.3-3.4 km (Stober and Bucher 2004, Durst and Vuataz 2000) with a pH of between 4.2 and 5.9 .
Fig. 1 a Upper Rhine Graben area with the most important geological lithologies and the main boundary faults at the eastern and western Rhine Graben rims. ( $Q A$ quaternary alluvium, $Q$ quaternary, $T W$ thermal water, $T$ tertiary) $\mathbf{b}$ The map is modified after Andrae and Osann (1893) and shows the working area, which is situated at the eastern Rhine Graben shoulder in the Odenwald forest, north of Heidelberg. c Profile transect through the E-W trending Schauenburg fault $(\mathbf{x}-\mathbf{y})$, juxtaposed to the $\mathrm{N}-\mathrm{S}$ trending main graben boundary fault

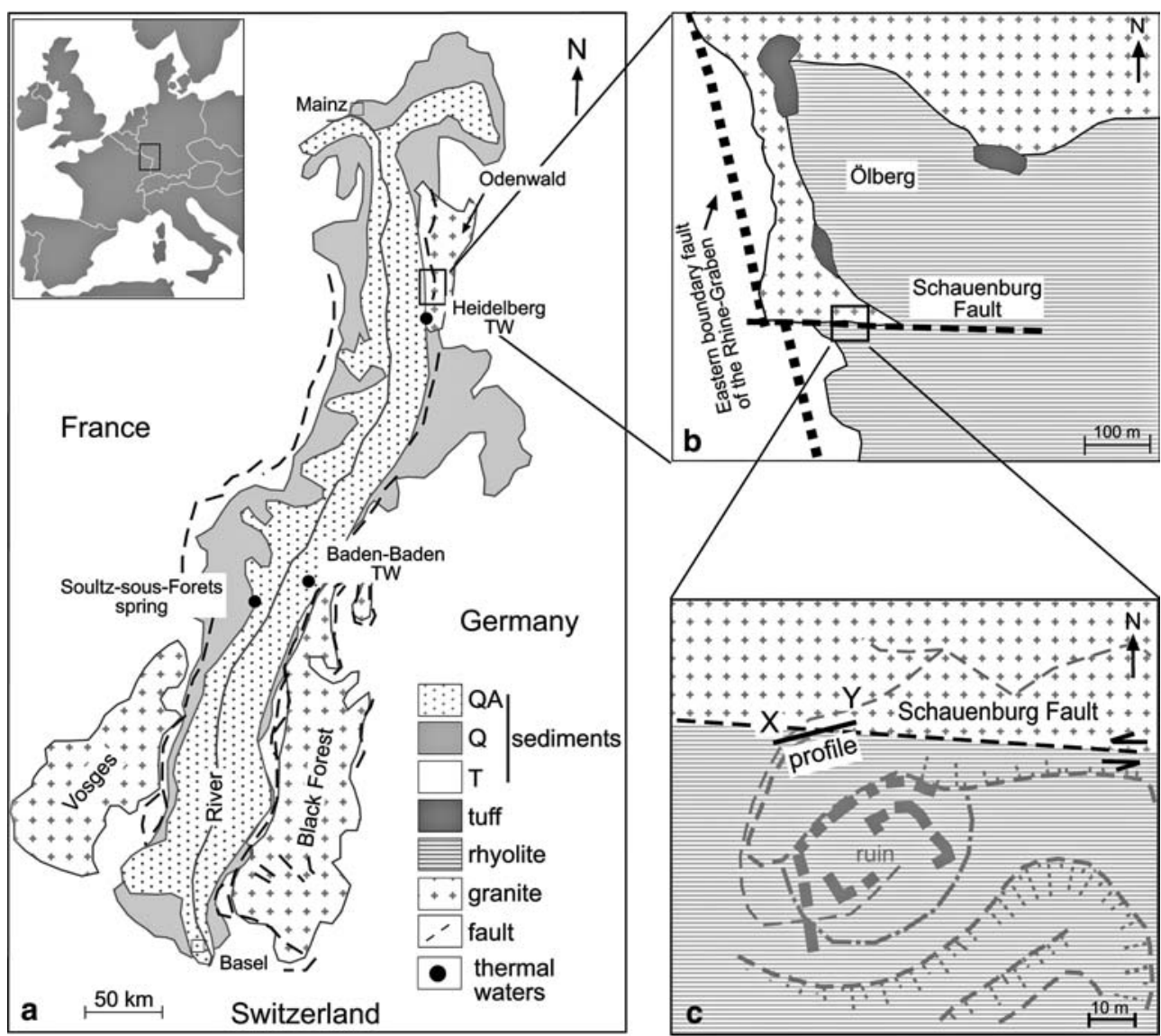


Saline, thermal waters are also found along the flanks of the Rhine Graben shoulder (Fig. 1). $\mathrm{NaCl}$ thermal water and radium-bearing $\mathrm{Ca}$-brines occur at BadenBaden, and also at the Heidelberg thermal borehole drilled in 1939 (Carlé 1975). The Heidelberg borehole was located $1 \mathrm{~km}$ west of the graben boundary fault, lying just $8 \mathrm{~km}$ south of the Schauenburg Fault locality. The exceptionally saline nature of the Heidelberg water recovered from $998 \mathrm{~m}$ depth was attributed to the interaction with Miocene salts (Carlé 1975). The high carbonate content and neutral to slightly alkaline character of these solutions is not typical of the crystalline brines described elsewhere in the region. At shallower levels in the borehole $(411$ and $570 \mathrm{~m})$, the saline waters are diluted by meteoric solutions and show clear signs of organic matter reactions (sulphur-bearing). More dilute and mixed waters, transitional between saline brines and meteoric solutions, are documented along the Rhine flank in this region by Bender (1995), with radiogenic isotope contents of these waters indicating residence times of up to 35,000 years at $3,000 \mathrm{~m}$ depth.

\section{The Schauenburg Fault}

The E-W trending Schauenburg Fault is situated along the eastern Rhine Graben shoulder, close to Heidelberg (Fig. 1) and lies ca. $280 \mathrm{~m}$ above the level of the graben flat. It forms a vertical contact between the outcropping Permian Rhyolite and the Carboniferous (Variscan) granite (Fig. 2) and provides an excellent opportunity for studying clay minerals in cataclastic deformed rocks. Geological mapping of the clay-rich fault zone reveals an oblique dextral strike-slip displacement of ca. $100 \mathrm{~m}$, with a down-throw to the south (A. Schleicher, unpub- lished Diploma Thesis). This fault intersects and appears to off-set the N-S trending Rhine Graben bounding fault just $100 \mathrm{~m}$ to the west (Fig. 1). Due to faulting, the granite-rhyolite structural contact has been altered to a weak, clay-rich cataclastic material, where locally the original igneous textures are no longer evident (Fig. 2). Numerous small faults, both in the granite and the rhyolite, can be recognized in surrounding areas, but they lack significant displacements or gouge zones.

$\mathrm{U}-\mathrm{Pb}$ dating on single zircons provided concordant intrusional ages for the Heidelberg granite of 342 and $332 \mathrm{Ma}$ (Hess and Lippolt 1996). Also well-defined ${ }^{40} \mathrm{Ar} /{ }^{39} \mathrm{Ar}$ ages of $332 \pm 3$ and $328 \pm 1 \mathrm{Ma}$ obtained on hornblendes and sericite-free plagioclase-confirmed the earlier $\mathrm{K}-\mathrm{Ar}$ and $\mathrm{Ar}-\mathrm{Ar}$ dates of around $335 \mathrm{Ma}$ (Lippolt et al. 1990). ${ }^{40} \mathrm{Ar} /{ }^{39} \mathrm{Ar}$ age measurements on sanidine, biotite and muscovite in the overlying PermoCarboniferous rhyolite give an age of $291 \pm 6 \mathrm{Ma}$. Including the age data on plutonic rocks of the Odenwald region, an age difference of about $45-55 \mathrm{Ma}$ exists between granite plutonism and rhyolitic volcanism (Hess and Lippolt 1996).

The geochemistry and isotopic signature of the Schauenburg Fault has been recently reported by Marbach (2002) and Marbach et al. (2005). Rare earth elements are notably concentrated along the fault zone, and indicate a shift in chemical environment from reducing to oxidizing conditions. A whole rock $\mathrm{Rb}-\mathrm{Sr}$ isochron of the altered granite yielded a late Jurassic age, interpreted to represent hydrothermal alteration. Based on $\mathrm{U}-\mathrm{Th}$ redistribution in the cataclasite, a younger event of between 100,000 years and $1 \mathrm{Ma}$ was recognized, whereby the youngest signatures (Quaternary) were attained from the margins of the altered fault zones, rather than its center.
Fig. 2 The geological cross section through the NW-SE trending Schauenburg Fault shows an almost vertical dip to the south, and marks the contact between Permian rhyolite and Variscan granite. Assuming that the rock in the south has a minimum thickness of $120 \mathrm{~m}$, an offset of $100 \mathrm{~m}$ can be possible. The profile shows finer grained rhyolitic rocks at the east and coarse grained granitic rocks at the west with a cataclastic, clay-rich gouge zone in the middle (pictures)
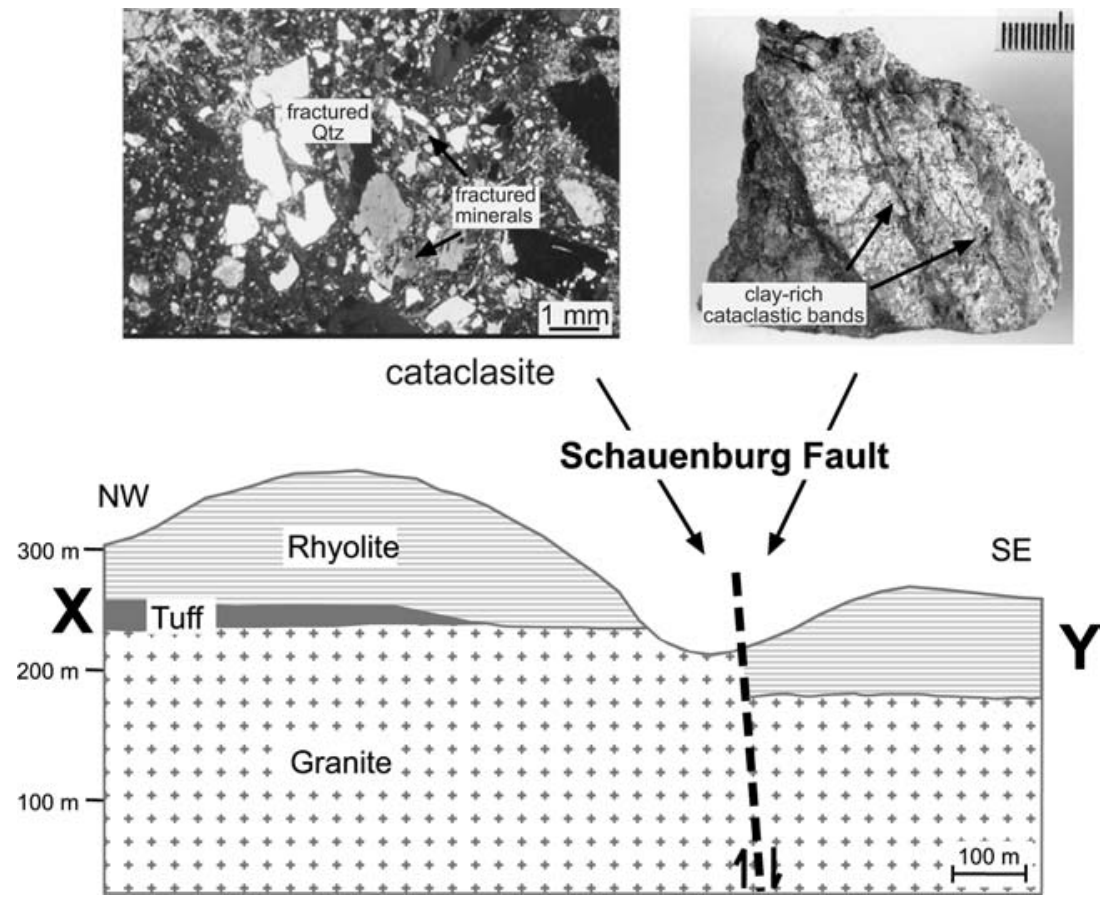


\section{Sample material and field relationships}

A total of 18 samples were collected from a surface outcrop across a ca. $50 \mathrm{~m}$ profile, traversing the fault zone. Blocks or cores were obtained by hammer or by drilling. Three segments could be recognized based on mesoscopic appearance: a rhyolitic wall rock zone to the south, with coarse-grained K-feldspar and quartz phenocrysts set in a fine-grained, felsic matrix; a finer grained cataclasite along the fault plane, characterized by strongly altered feldspar grains and thin, dark veins filled with cataclastic material (Fig. 2); and a highly fractured granitic wall rock to the north of the fault, with notably friable coarse-grained alkali feldspars and abundant biotite.

\section{Analytical methods}

Samples were investigated by optical microscopy, X-ray diffraction (XRD) and scanning electron microscopy (SEM). Representative specimens were then selected for more detailed studies using X-ray texture goniometry (XTG), high-resolution transmission electron microscopy (HRTEM) and analytical electron microscopy (AEM)

For XRD studies, a Siemens 500 Diffractometer was used to obtain random powder and oriented, textural results. Preparation of rocks followed the analytical methods described by Moore and Reynolds (1997). Wellwashed samples were crushed into small pieces and disaggregated in an ultrasonic bath for at least half an hour. The $<2 \mu$ clay fraction was separated by centrifugation and prepared by pipetting $45 \mathrm{mg}$ of clay suspended in $1.5 \mathrm{ml}$ of distilled water onto $3 \mathrm{~cm} \times 3 \mathrm{~cm}$ glass slides. To aid the identification of the clay minerals, the samples were measured in a variety of states, including Ca-saturated, ethylene-glycol treatment and heating up to $480^{\circ} \mathrm{C}$ for $1 \mathrm{~h}$. The $d$-values were calibrated against the position of quartz reflections, and the full-width-at-half-maximum (FWHM) calibrated using the standards of Warr and Rice (1994). Selected samples were used for measuring the crystallographic-preferred orientation of illite by XTG (e.g. Oertel 1985; Schmid and Casey 1986), which were measured using an Enraf-Nonius CAD4 automated single-crystal diffractometer with a Mo radiation source, equipped with a custom-built X-ray polefigure stage. The preferred orientation data of illite were determined utilizing the (001) plane basal reflection (at 10 $\AA$ ). The measured X-ray intensity data were corrected for background and absorption effects, and then normalized so that the results are independent of mineral concentration (van der Pluijm et al. 1994). Normalized intensity data are expressed in multiples of random distribution (m.r.d.; Wenk 1985), where higher m.r.d values represent a larger degree of mineral preferred orientation.

Scanning electron microscopy was undertaken on gold- or carbon-coated samples prepared as small rock pieces (for secondary electron images) and thin sections (for backscattered images). Qualitative analyses of mineral composition were obtained by energy dispersive spectroscopy (EDS). Three representative samples were also investigated by HRTEM and AEM following the analytical procedure outlined by Peacor (1992) and Warr and Nieto (1998). Samples were vacuum impregnated with L.R. White resin, to prevent collapse of smectite interlayers, following the procedure of Kim et al. (1995). Small (1 mm diameter) sections were picked from the more homogenous and representative areas of the thin sections, then ion milled and carbon coated. TEM study of the material combined latticefringe imaging and selected area electron diffraction (SAED) patterns of selected sites of interest. Microscopy was undertaken using a Philips CM 12 scanning-transmission electron microscope (STEM) with a Kevex Quantum solid-state detector. It operates at $120 \mathrm{kV}$ and a beam current of $20 \mathrm{~m} \mu \mathrm{A}$. All high-resolution lattice fringe images were obtained at $\times 100,000$ magnification. Quantitative microchemical data were obtained by EDS in scanning transmission electron mode using a beam diameter of $5 \mathrm{~nm}$ and a scanning area of $30 \mathrm{~nm} \times 30 \mathrm{~nm}$, and compositional data were calibrated using the $\mathrm{k}$-values of available laboratory standards.

\section{Results}

Sample characteristics and mineral assemblages

The granite and rhyolite collected across the Schauenburg Fault are predominantly coarse-grained, except for a ca. $4 \mathrm{~m}$ wide, intensely deformed fine-grained cataclastic zone developed along the fault plane (Fig. 2). The primary mineral components of both rock types are quartz, K-feldspar, plagioclase and biotite. Secondary minerals are plagioclase, sericite and a number of accessory minerals, notably hematite and rutile. Hand specimens of the less altered granite and rhyolite lithologies have an isotropic texture, which becomes increasingly overprinted by a brittle cataclastic fabric toward the fault plane.

Characteristically, the rhyolite is dominated by various phenocrysts $(>2-3 \mathrm{~mm})$ in a fine-grained matrix. Optical microscopy reveals $30-35 \%$ of anhedral, undulose quartz grains with strongly sutured, sometimes recrystallized rims. Large altered K-feldspars (20-25\% of grains) show typical Carlsbad twinning and pertitic textures, but in contrast, the plagioclase and also biotite are strongly altered, and show signs of localized intracrystalline deformation. Open fractures within large quartz and feldspar grains are partly in-filled with granular, finegrained quartz and later Fe-oxide phases (particularly hematite). The degree of brittle deformation increases toward the center of the fault plane, where the rocks are intensely fractured.

In contrast, the granite is coarser grained with characteristically large phenocrysts of K-feldspar, quartz and 
biotite. Quartz, which makes up ca. $40 \%$ of the rock, shows only minor degrees of intracrystalline deformation, expressed by undulose extinction. The cracks in these minerals are usually unmineralized, but the sericite alteration of feldspars is notably more intense than in the rhyolite, with almost complete alteration of plagioclase grains.

The $4 \mathrm{~m}$ wide cataclastic zone is marked by a transitional increase in the degree of rock alteration, whereby the fault material becomes notably incohesive, forming a clay-bearing cataclasite. It is composed of a mixture of angular, small-sized $(<1 \mathrm{~mm})$ granitic and rhyolitic derived clasts, set in a heavily altered very finegrained clay matrix (Fig. 2). Anhedral quartz clasts (40$45 \%$ ) show intensely dissolved mineral rims with a strong intracrystalline deformation, but almost no recrystallization. Strongly altered and fractured feldspar (30-40\%) and deformed biotite crystals also occur. Whole rock geochemical investigations confirm the mixed origin of material in the cataclasite, but show a stronger similarity with the granite (Marbach et al. 2005).

\section{$\mathrm{X}$-ray diffraction analysis}

The whole rock powder XRD analysis confirms the mineralogical assemblage determined from thin section study. In addition to quartz, mica and feldspar (K-feldspar and albite) as main components, apatite, calcite and hematite are identified as typical accessory phases.

In contrast, the clay-sized fraction $(<2 \mu \mathrm{m})$ is dominated by illite, kaolinite, mixed-layered illite-smectite and occasional smectite. Comparing the basal (001) clay mineral XRD patterns of the different rock types reveals differences in air-dried, glycolated and heat-treated preparations, indicating the presence of mixed-layered smectite (Fig. 3). In air-dried samples, the XRD patterns typically have a ca. $10.3 \AA$ peak that shifts to ca. $10 \AA$ when treated with ethylene glycol, with a weaker reflection appearing at ca. $11.1 \AA$. These characteristics suggest a R3 illite-smectite polytype as the dominant illitic phase, characterized by long-ranged ordering. The presence of interlayers of smectite is confirmed by heating to $480^{\circ} \mathrm{C}$, with the collapse of layers and formation of sharp illite reflections at $\sim 10 \AA$. Similar mineral assemblages were detected in the fault zone, with broad reflections of illitic and illite-smectite mixtures. Discrete smectite reflections were observed in only a few granite samples.

All samples contained significant amounts of kaolinite, with a basal reflection at $7.1 \AA$. This mineral phase becomes thermally unstable at $500-550^{\circ} \mathrm{C}$, indicating the kaolinite polytype (sensu stricto), as opposed to the higher temperature polytype of dickite (Brindley and Brown 1980; Ehrenberg et al. 1992). Figure 4 shows intensity (cps) variations and FWHM values for the (001) illite and (001) kaolinite reflections across the fault zone. Differences in peak intensity are considered to

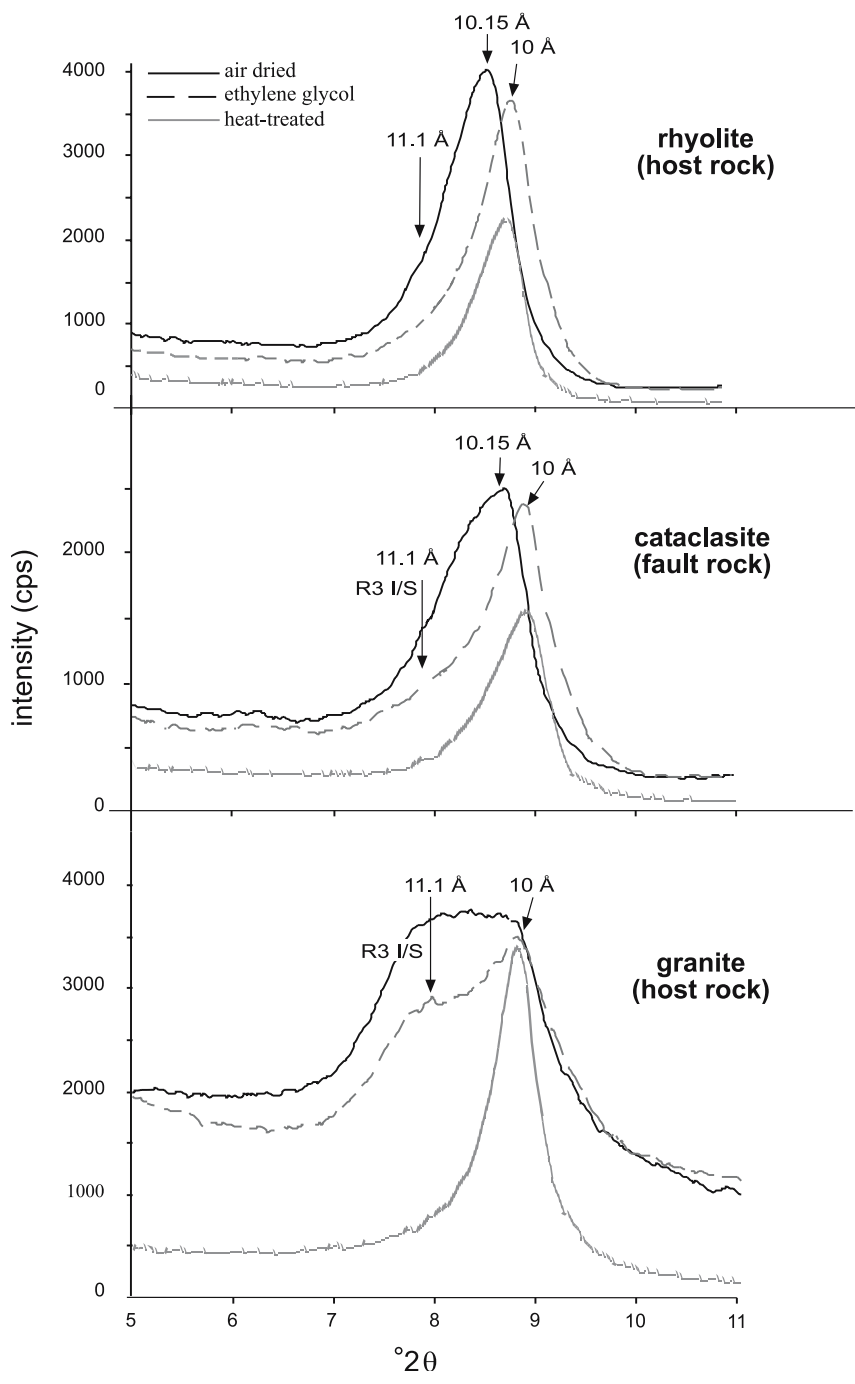

Fig. 3 X-ray diffraction characteristics of the rhyolite, cataclasite and granite rocks from the Schauenburg fault. The clay mineral 001 reflections of illite and illite-smectite, occurring between $5^{\circ} 2 \theta$ and $11^{\circ} 2 \theta$ are shown for air-dried, glycolated and heat-treated preparations

largely reflect relative changes in mineral abundance, as the texture slides were prepared using constant amounts of clay, with consistent and reproducible degrees of particle orientation and heterogeneity. Three intensity maxima can be recognized for illite across the fault zone. Each maximum is characterized by a continuous increase in peak height, with a surprisingly low degree of fluctuation between samples. Although we have not quantified the precise amount of illite in these samples, the areas of enrichment occur in both fractured wall rock, as well as in the center of the fault zone. The maxima, therefore, seem to correspond to the position of highly fractured rupture zones or minor faults; however, due to poor exposure, the exact position of displacement planes could not be recognized in the field.

Variations in the FWHM of illite also occur across the fault profile. The lowest values occur in the rhyolite $\left(0.69-0.82^{\circ} 2 \theta\right)$, the highest values in the granite 
Fig. 4 Peak broadening (FWHM, dashed line) and intensity (cps, solid line) results of the 001-illite and 001kaolinite reflections, which are plotted against the profile transect. The samples contain significant amounts of kaolinite in the cataclastic fault plane, whereas there are three specific illite peaks in all rock types, defining some probably pre-rift structures. Both illite and kaolinite crystallite-sizes increase toward the granitic rocks

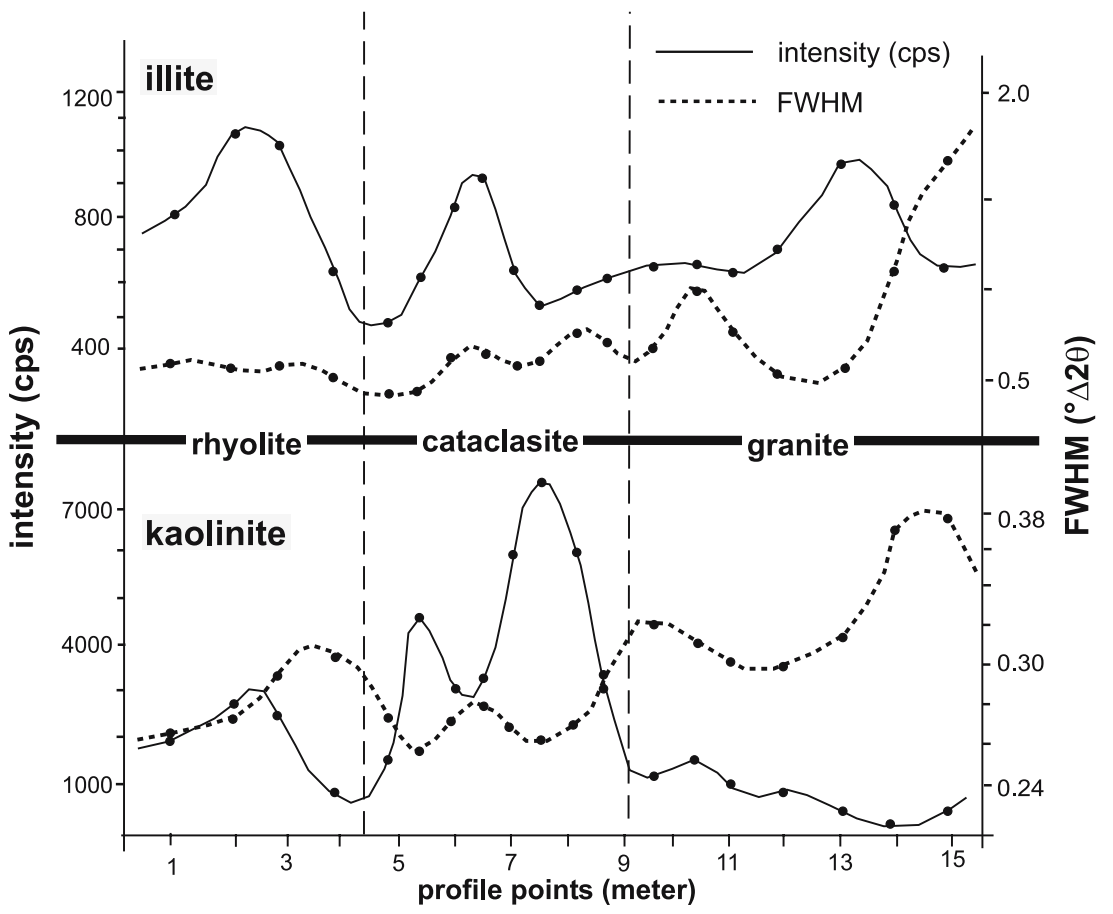

(mean $=1.2^{\circ} 2 \theta$ ), whereas the fault zone is intermediate between the two $\left(\right.$ mean $\left.=0.82^{\circ} 2 \theta\right)$. Notably higher degrees of fluctuation occur both in the fault zone and the granite. As these variations are maintained following treatment with ethylene glycol, the FWHM values are considered to largely reflect differences in mean crystallite size with lesser influence from the presence of mixedlayered smectite.

A mixture of $1 \mathrm{M}_{\mathrm{d}}$ and $2 \mathrm{M}_{1}$ illite polytypes could be recognized by visual examination of the random powder XRD patterns, following the methods described in Grathoff and Moore (1996). The dominant polytype in all samples is a $1 \mathrm{M}_{\mathrm{d}}$ illite variety with distinct peaks at 3.66 and $3.07 \AA$, whereas a $2 \mathrm{M}_{1}$ illite is present only in minor quantities, with diagnostic reflections at 2.98, 2.86 and $2.80 \AA$, and is most abundant in the rhyolite. A quantification of illite polytypes was not conducted due to the large degree of overlapping reflections from other mineral phases, making reliable measurement of peak areas and intensities difficult.

Fig. 5 Examples of X-ray texture goniometer (XTG) pole figures from three selected samples of the Schauenburg Fault transect. The figures show the clay preferred orientation for the rhyolite, the cataclasite and the granite, where each contour represents multiples of random distribution (m.r.d.)
The intensity and FWHM variations of kaolinite across the fault zone show a simpler pattern than the illitic phases (Fig. 4). Based on the high kaolinite peak intensities within the cataclasite, this mineral can be inferred to be most abundant along the fault zone. In contrast, kaolinite is least abundant in the granite. The low FWHM values of the (001) kaolinite reflection of fault zone samples also reflect thicker crystallite packets within the fault core. The highest FWHM values, reflecting small mean crystallite thickness, correspond with the lower amounts of kaolinite in the granite unit.

\section{Rock texture}

The preferred orientations of illite crystallites for the three representative samples (rhyolite, cataclasite and granite), measured using the (001) reflection at $10 \AA$, are plotted as contoured X-ray intensity data on equal-area, lower hemisphere projection pole-figures (Fig. 5). The

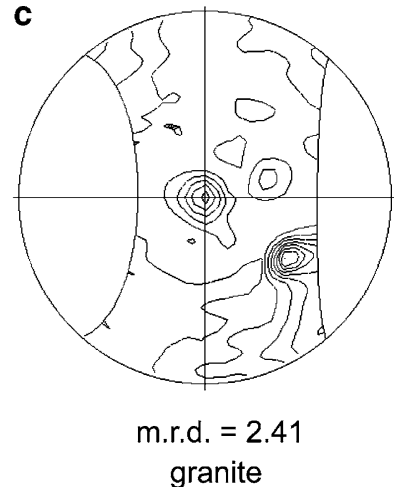

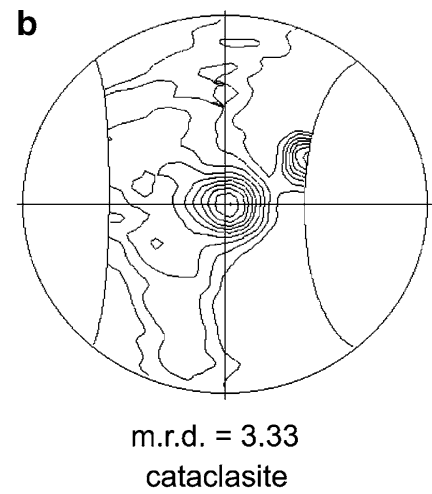

granite

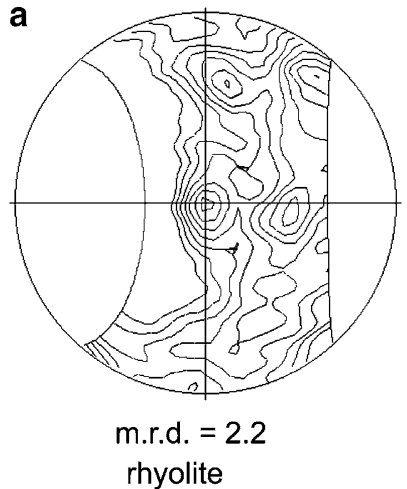


maxima for each sample have been rotated to the center of the projection to reveal the shape and the intensity of fabric elements. The X-ray goniometry plots reveal complex fabrics across the fault zone. The textural patterns of the rhyolite are characterized by four several closely spaced maxima attributable to the presence of relatively large stacks of illite (and kaolinite) as observed by electron microscopy (Fig. 5a). The poorly defined maxima (up to m.r.d of 2.2) reflect the variable orientation of clay stacks in the sample. In contrast, the cataclasite sample contains two tightly grouped maxima, defining a better-developed fabric (m.r.d. of 3.33; Fig. 5b). Microscopic observations similarly reveal the orientation of illite and kaolinite stacks to vary in the cataclasite samples with their basal planes lying subparallel to the fault plane. A well-defined fabric is absent in the granite sample (Fig. $5 \mathrm{c}$ ), similar to the texture of the rhyolite (Fig. 5a).

Microstructure and chemical analysis

\section{Scanning electron microscopy}

Secondary and back-scattered electron microscopy images combined with EDX analyses reveal a variety of
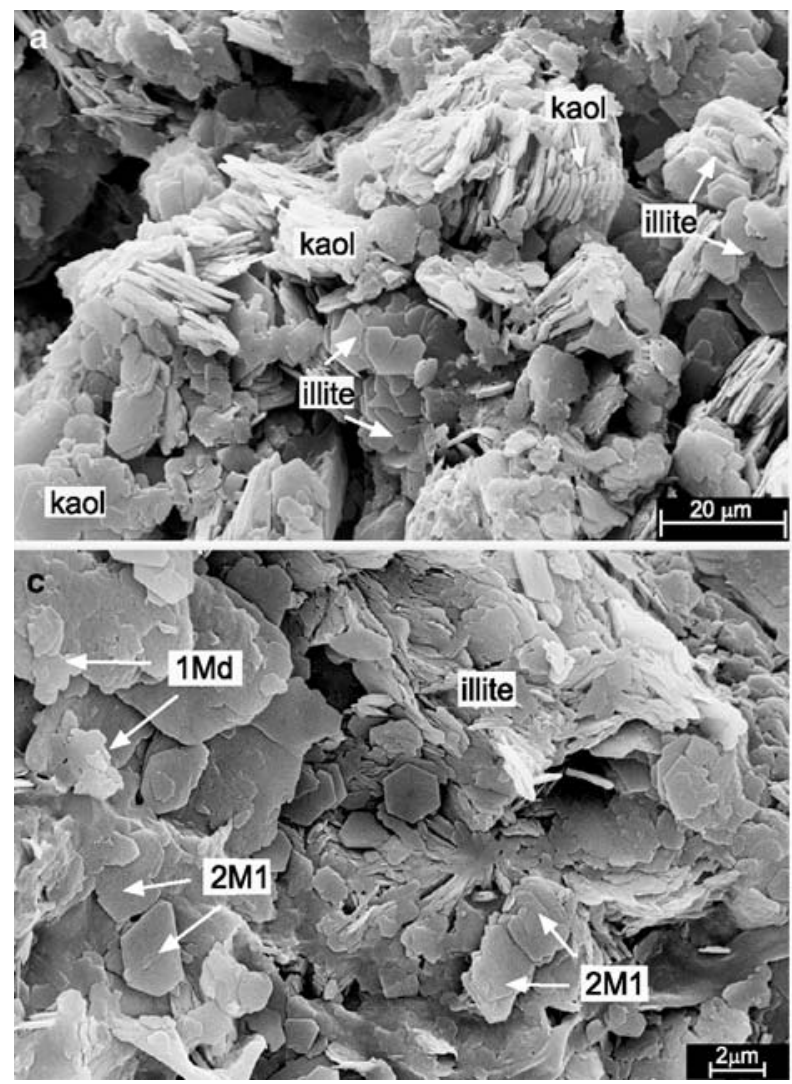

Fig. 6 SEM illustrations of the rhyolitic, the granitic and the cataclastic samples of the Schauenburg Fault region. a Vermiform stacks of illite and kaolinite grow side by side in feldspar pore spaces. b BSE image of a pore filling in the cataclasite, with a feldspar to illite reaction appearing to be post-dated by the younger illite and kaolinite particle shapes, sizes and microstructural features, which vary across the fault zone (Fig. 6). The cataclasite minerals are generally $0.5-4 \mu \mathrm{m}$ and occur mainly as pore fillings associated with areas of high porosity (Fig. 6a). Some vermiform packets of blocky kaolinite are observed, stacked linearly up to $10 \mu \mathrm{m}$ in length. Pores appear to have formed primarily by the dissolution of quartz and feldspar, whereby plagioclase appears to be dissolved completely in the claysized fraction. A number of reaction textures can be observed, with the feldspar to illite reaction appearing to be post-dated by the younger growth of kaolinite crystals in association with the dissolution of quartz (Fig. 6b).

A range of illite crystal shapes can be observed by SEM in all units across the fault zone. Relatively large subhedral to euhedral crystals of illite occur within pore fillings (Fig. 6c), together with smaller illite particles having characteristic irregular edges. The latter are grouped together within larger aggregates. The wellcrystallized euhedral kaolinite within the pores of the cataclasite has an average grain-size of ca. $2 \mu \mathrm{m}$, and is post-dated by neocrystallization of smaller Fe-oxide particles (Fig. 6d).
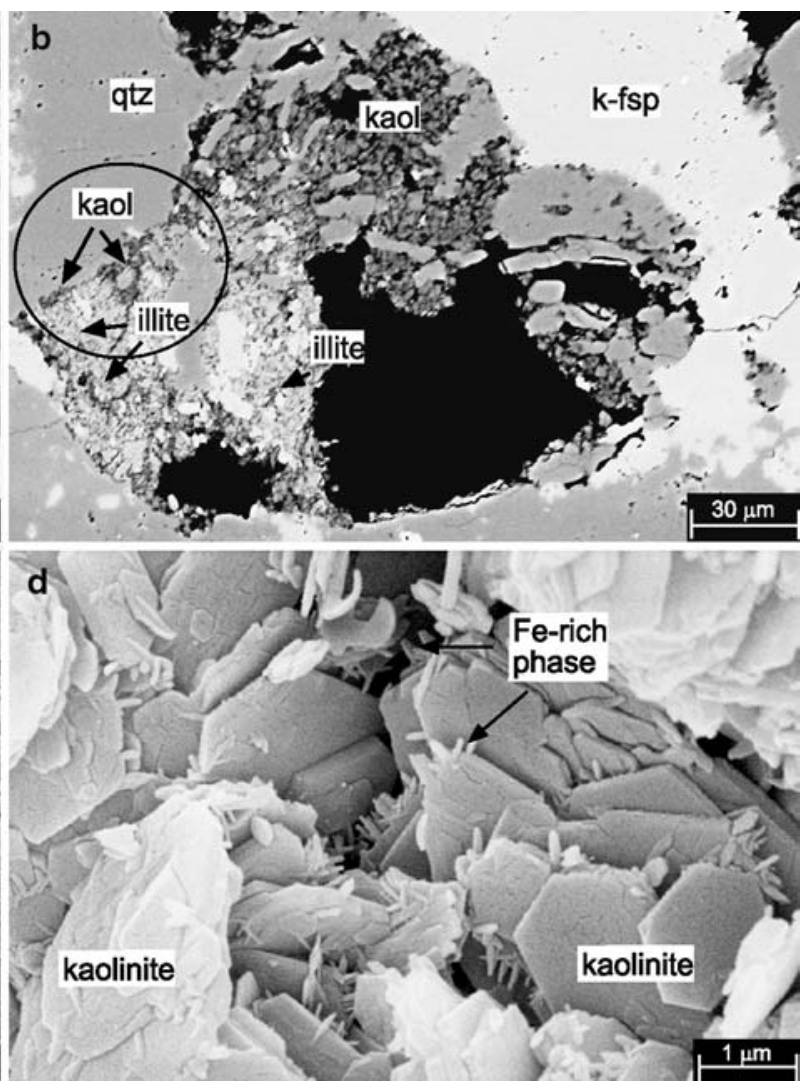

growth of kaolinite crystals in association with the dissolution of quartz. c Larger, pseudohexagonal $2 \mathrm{M}_{1}$ illite polytypes grow together with smaller, slightly dissolved $1 \mathrm{M}_{\mathrm{d}}$ illites in pore spaces. $\mathbf{d}$ Hexagonal crystallites of kaolinite are overgrown with small, $\mathrm{Fe}-$ rich minerals 


\section{High-resolution transmission electron microscopy/ analytical electron microscopy}

Representative HRTEM images show typical mineral assemblages, and their microstructural characteristics of the rhyolitic, cataclasite and granitic samples are given in Figs. 7, 8, 9. At low magnification, the rhyolite contains packets of $15-30 \mathrm{~nm}$ thick illite crystallites stacked together with ca. $100 \mathrm{~nm}$ thick kaolinite (Fig. 7a). The contacts between illite and kaolinite packets are planar and commonly characterized by low-angle crystallite boundaries. Here, kaolinite is not the most abundant clay mineral observed. Dominant are packets of discrete illite and illite-smectite mixed-layered phases, which show relatively low concentrations of intracrystalline defects (e.g. layer terminations and lattice distortion) and a variety of crystallite thicknesses (Fig. 7 b, c). Straight packets of discrete illite, at least $80 \mathrm{~nm}$ long and $20 \mathrm{~nm}$ in thickness, occur with a constant $d$-value. The occurrence of some $20 \AA$ periodicity in both fringe images and SAED patterns indicate these packets to be of the $2 \mathrm{M}_{1}$ polytype.

Illite-smectite mixed-layered minerals are also common in the rhyolite samples. These layers are stacked optically parallel with discrete illite packets (Fig. 7c). Smectite layers can be recognized by their higher contrast, irregular lattice fringes and ca. $12 \AA$ thicknesses. Long-range ordering, presumably R3, is evident by the reoccurrence of single smectite layers stacked optically parallel between 2 to 5 illite layers. The SAED patterns of the illite-smectite indicate a $1 \mathrm{M}_{\mathrm{d}}$ polytype, with marked streakings in non- $00 l$ reflections.

Four distinctly different minerals can be recognized in the cataclasite sample (Fig. 8). (1) Abundant illite with typical $10 \AA$ layers, (2) illite-smectite mixed layers that are more common than in the rhyolite sample, (3) discrete particles of smectite, with typical anastomosing 12 $14 \AA$ layers, and (4) large quantities of thick kaolinite crystallites. All these mineral phases occur in crystallite
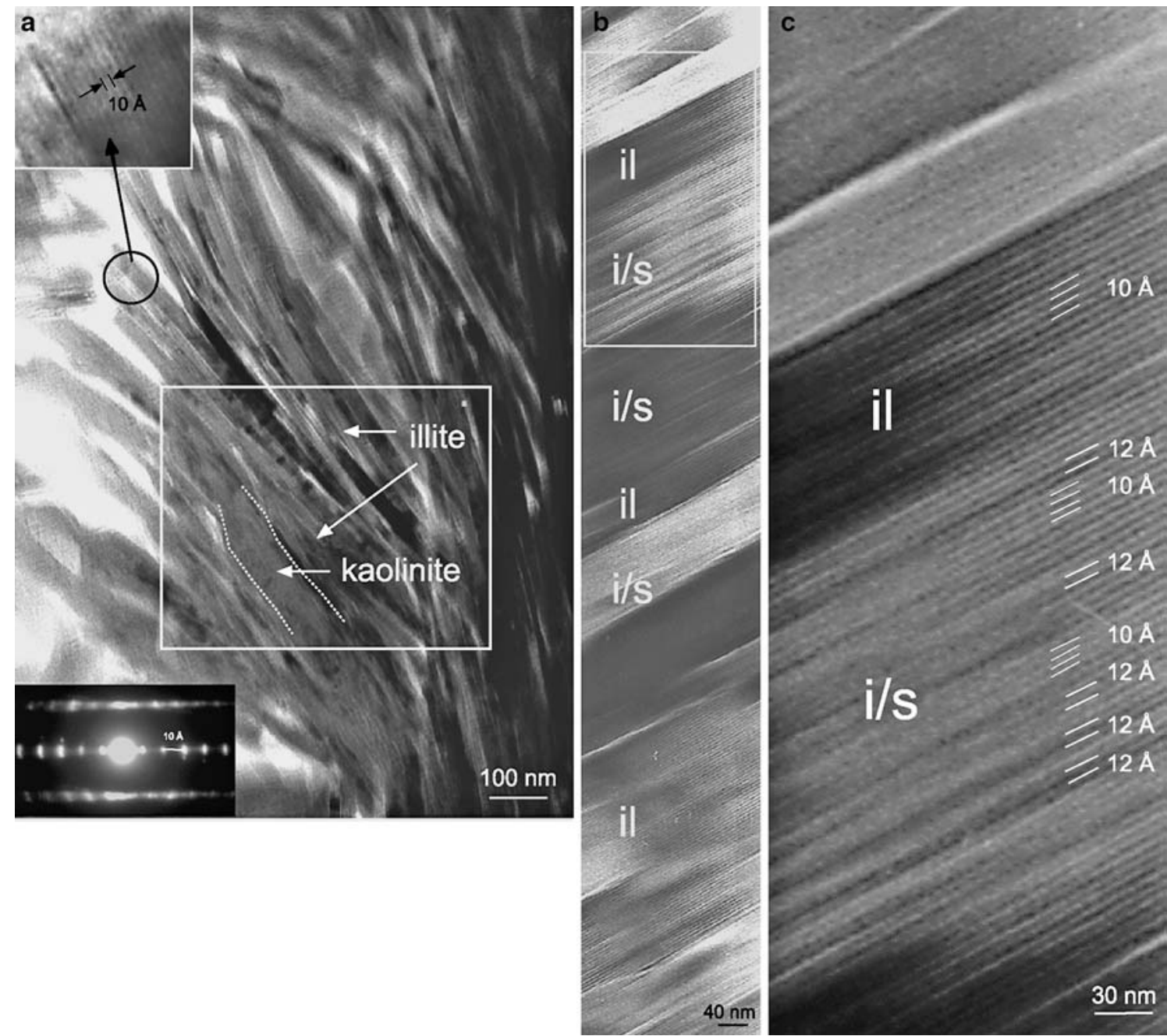

Fig. 7 TEM lattice fringe image and SAED pattern from a selected sample of the rhyolitic rock. a Low magnification image with $10 \AA$ illites, growing juxtaposed against kaolinite. b long range ordering (R3) illite-smectite, alternating with discrete packets of $2 \mathrm{M}_{1}$ illites with fewer layer terminations 

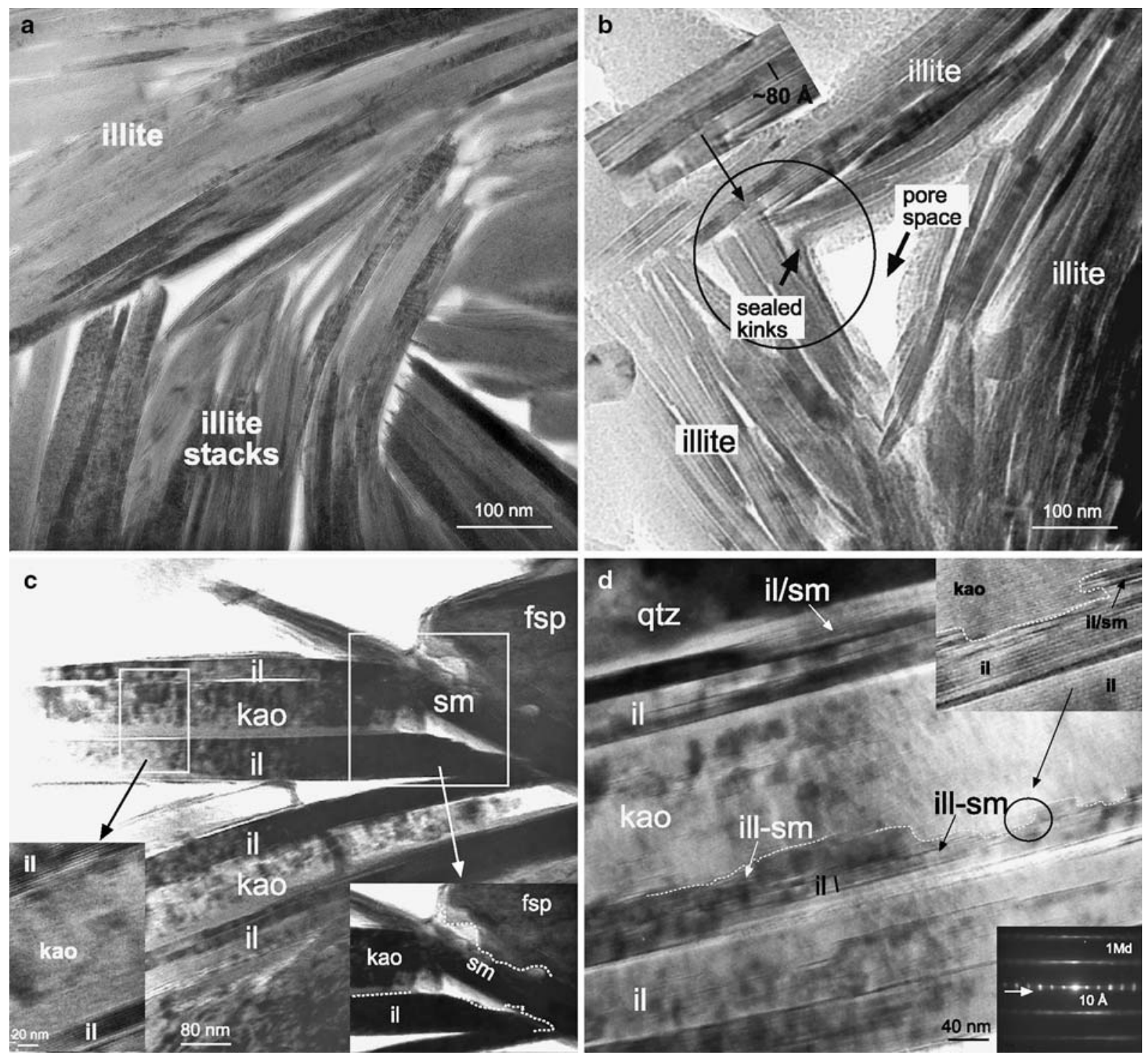

Fig. 8 Lattice fringe images and SAED pattern of the cataclastic fault plane. a Characteristically irregular $1 \mathrm{M}_{\mathrm{d}}$ illite with frayed margins, which juxtapose against curved illite grains. b Remnants of kink bands developed in illite packets are observed. c, d The relationship between illite, illite-smectite and kaolinite. Kaolinite

packets commonly stacked parallel or subparallel to their basal planes. High angle grain boundaries also occur, with intersections between clay edges and particle surfaces (Fig. 8a, c, d). The edges of $1 \mathrm{M}_{\mathrm{d}}$ illite crystallites, $10-20 \mathrm{~nm}$ in thickness, show characteristically irregular, frayed margins, which juxtapose against curved illite grains, probably formed during rock deformation (Fig. 8a). Remnants of kink bands developed in illite packets are also observed (Fig. 8b), whereby the illite is interpreted to post-date kink formation. These structures are associated with significant pore space within fold hinge regions.

The formation of kaolinite packets (on average ca. $80-100 \mathrm{~nm}$ thick) is commonly seen to replace illite and illite-smectite packets (Fig. 8c, d). The contacts between

packets have formed by replacement of the illite and illite-smectite packets, and the contact between kaolinite and illite layers are often planar. Kaolinite-illite-smectite grain contacts are notably uneven, reflecting dissolution surfaces. The streaked $h k l$ reflections on the SAED pattern indicate that stacking is disordered

kaolinite and illite layers are often planar, whereas the kaolinite, illite-smectite grain contacts are notably uneven and reflect dissolution surfaces. Similar TEM replacement textures have been described by Robertson and Eggleton (1991) at kaolinite-muscovite contacts in altered granites of tin deposits in Australia. Smectite in the cataclasite occurs exclusively as individual particles, which have formed between pre-existing clay packets, and likely reflect neocrystallization in pore spaces.

Smectite particles with similar characteristics and origin are also observed in the granite sample. Areas of discrete smectite (Fig. 9a) have discontinuous, wavy layers with variable spacing between 12 and rarely $14 \AA$ reflecting structural or compositional heterogeneities (Kim et al. 1995). Defect-rich areas with abundant dis- 

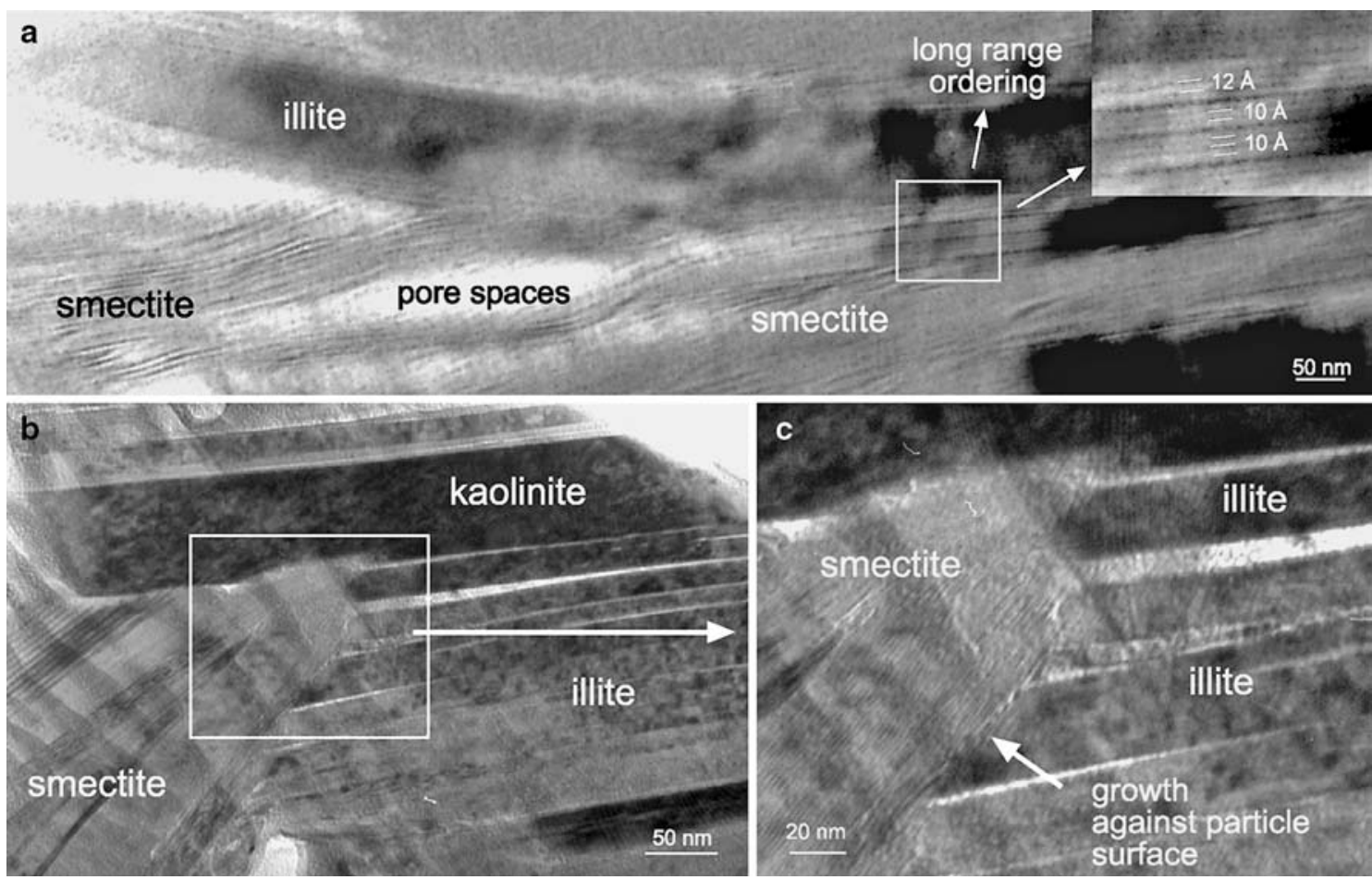

Fig. 9 High magnification images of the granitic rock sample. (a-c) Discrete smectite has discontinuous, wavy layers with variable spacing between 12 and rarely $14 \AA$. As in the rhyolite sample, the illite-smectite mixed layered structures are characterized by long-ranged orderings

locations (layer terminations) are seen to have grown against both particle surfaces and edges of illite and illite-smectite crystallites (Fig. 9b, c), although precipitation of smectite layers does appear to have been associated with dissolution of both illite and kaolinite particle surfaces. As in the rhyolite sample, the illitesmectite mixed-layered structures are characterized by long-ranged ordering.

\section{Compositions of illitic minerals}

The structural formulae of illites (normalized to $\mathrm{O}_{10}$ $\left.(\mathrm{OH})_{2}\right)$ based on AEM analyses of the rhyolite, cataclasite and granite samples are listed in Table 1, and significant cations are plotted against Si content in Fig. 10. As $\mathrm{Ca}$ is absent or only present in trace amounts, it is not included here.

Each of the samples can be distinguished on the basis of their octahedral and interlayer cation content. The rhyolite contains illite with compositions comparable to the Silver Hill illite (1Mt-1) of Hower and Mowatt (1966; open squares in Fig. 10) and the felsic volcaniclastic illite of Inoue et al. (2004; open triangles in Fig. 10), with an average $\mathrm{K}$ content of 0.64 per unit formula. In contrast, the illitic phases in the cataclasite are characteristically Al-rich $\left(\Sigma \mathrm{Al}^{\mathrm{IV}} 0.79\right)$ and $\mathrm{Mg}-\mathrm{Fe}$ poor, suggesting significant substitution of octahedral cations by Al. The lower interlayer cation content reflects the abundant mixed-layered smectite as also observed by TEM. Two compositions of illitic phases can be recognized in the granite sample. An Al-rich illite (G1), similar to that found in the cataclasite, but with less octahedral substitution of $\mathrm{Al}$ for $\mathrm{Mg}$ and $\mathrm{Fe}$, and a Si-rich, Al-poor phase, with a high interlayer cation content (G2), reflecting a high layered charged mineral. The latter illitic phase has an average $\mathrm{K}$ and $\mathrm{Na}$ content of 0.28 and 0.37 respectively, probably reflecting the presence of some paragonite interlayers.
Table 1 Microchemical data for illite in the Schauenburg Fault zone, normalized to $\mathrm{O}_{10}(\mathrm{OH})_{2}$ with interlayer summary ( int) and octahedral summary ( ooct)

\begin{tabular}{|c|c|c|c|c|c|c|c|c|c|}
\hline $\begin{array}{l}\text { Illite composition } \\
\text { normalized to } \mathrm{O}_{10}(\mathrm{OH})_{2}\end{array}$ & $\mathrm{Si}$ & $\mathrm{Al}^{\mathrm{iv}}$ & $\mathrm{Al}{ }^{\mathrm{vi}}$ & $\mathrm{Mg}$ & $\mathrm{Fe}$ & Loct & K & $\mathrm{Na}$ & Sint \\
\hline Rhyolite & 3.53 & 0.47 & 1.40 & 0.31 & 0.23 & 0.54 & 0.64 & 0.08 & 0.72 \\
\hline Cataclasite & 3.21 & 0.79 & 2.06 & 0.06 & 0.05 & 0.11 & 0.24 & 0.02 & 0.26 \\
\hline Granite-1 & 3.88 & 0.12 & 1.42 & 0.18 & 0.01 & 0.19 & 0.74 & 0.20 & 0.95 \\
\hline Granite-2 & 3.14 & 0.86 & 1.67 & 0.32 & 0.19 & 0.52 & 0.28 & 0.37 & 0.66 \\
\hline Illite standard & 3.39 & 0.62 & 1.35 & 0.26 & 0.41 & 0.67 & 0.69 & 0.00 & 0.69 \\
\hline
\end{tabular}




\section{Discussion}

Fault rocks along the Schauenburg Fault, located at the eastern Rhine Graben margin, are enriched in clay minerals with reaction textures representing a retrograde sequence of back-reactions from $2 \mathrm{M}_{1}$ illite polytypes to $1 \mathrm{M}_{\mathrm{d}}$ (R3) illite-smectite, to discrete smectite and kaolinite. The cataclasite, marking the fault plane, is particularly enriched in pseudo-hexagonal vermiform kaolinite stacks and illite-smectite assemblages. These patterns are interpreted to reflect fault-controlled circulation of low temperature hydrous fluids that were responsible for clay mineral formation. Based on our XRD, XTG and electron microscopy study, this retrograde history of clay mineral reactions is discussed in
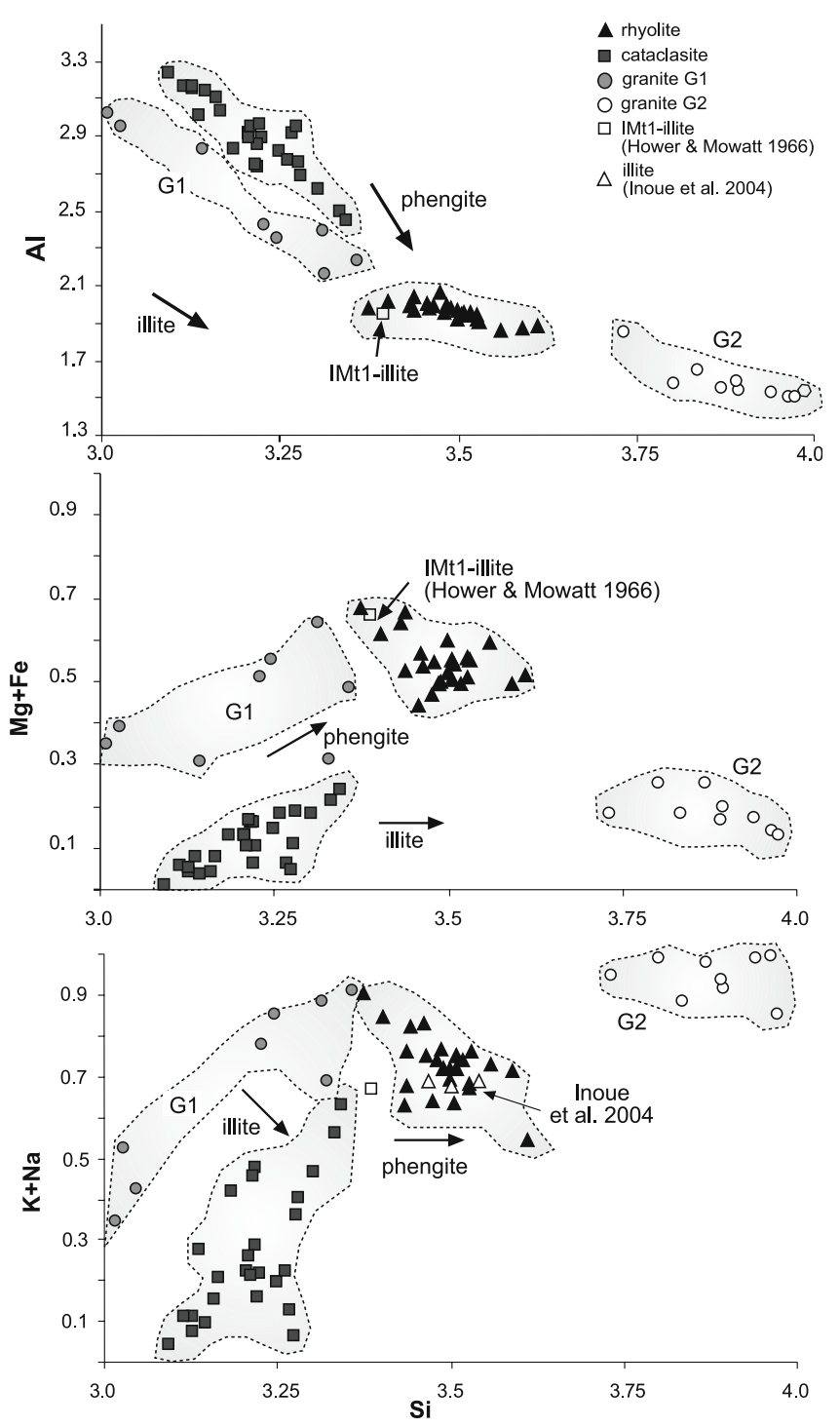

Fig. 10 Chemical composition diagrams of illite from the different lithologies plotting $\mathrm{Al}$ and the octahedral and interlayer cations against silicon. The circles indicate the illite compositions in the different rock types. terms of initial hydrothermal illitization of feldspars, followed by exhumation and focused fluid flow along the fault zone within the uplifting rift shoulder. A schematic reconstruction of the mineral textures and rock fabrics of the Schauenburg Fault is presented in Fig. 11.

\section{Hydrothermal illitization of feldspars}

The first stage of alteration within the fault rocks was the crystallization of well-developed pseudo-hexagonal $2 \mathrm{M}_{1}$ illite crystals (sericite), formed predominantly by the dissolution of feldspar grains (Fig. 11a). The plagioclase feldspar has been completely altered in the clay-sized fractions of most rock types across the fault zone, and dissolution and illite crystallization in pore spaces is common within K-feldspar grains (Figs. 6b, 11a).

This $2 \mathrm{M}_{1}$ illitic phase shows features typical of fluiddominated, hydrothermal mineral growth. The sharp illite peaks (XRD) of the rhyolite samples reflect wellordered crystals (Fig. 6c), with a tendency toward Kphengitic (Si-rich) compositions (Fig. 9a). The stage of illite formation, dated to be of late Jurassic age (Marbach et al. 2005), took place in an environment of regional scale fluid flow during Mesozoic extension. This tectonic setting is associated with the breakup of Pangaea and the initial stages of Atlantic rifting and burial by platform sediments across the peneplaned Variscan basement (Clauer et al. 1995; Brockamp et al. 2003). The occurrence of pure illite in all rock types across the Schauenburg Fault zone, and its common occurrence in the more impermeable Permian rhyolite unit, implies this stage of hydrothermal alteration was more pervasive and occurred prior to Tertiary rifting. Although this initial stage of extensive rock alteration was fracture related, there is little indication to suggest that the Schauenburg Fault existed as a distinct structure at this time.

The phengitic composition of the pure illite phase is comparable with a number of low temperature illites formed under a range of diagenetic, low temperature metamorphic and hydrothermal conditions (Hunziker et al. 1986; Bove et al. 2002; Inoue et al. 2004). Yoder and Eugster (1955) and Velde (1965) determined that the $1 \mathrm{M}_{\mathrm{d}} \rightarrow 2 \mathrm{M}_{1}$ white mica transformation occurs experimentally in the temperature range of $125^{\circ} \mathrm{C}(400 \mathrm{MPa})$ to $350^{\circ} \mathrm{C}$, and in natural prograde metamorphic sequences this transition occurs predominantly under anchizonal conditions $\left(200-300^{\circ} \mathrm{C}\right)$ and is complete by the beginning of the greenschist facies (Frey 1987). The direct dissolution of feldspar and precipitation of pure illite (sericite) is a reaction driven by proton attack and therefore triggered by the circulation of acid or neutral solutions (Brockamp et al. 2003) likely originating from granite fluids of the graben region. We suggest that the Jurassic Schauenburg fluids were similar in composition to the mildy acidic hot thermal brines that have been recovered from depths in the basement of the rift and in adjoining areas (Soultz-sous-Forêts, Cronenbourg, 
Fig. 11 Schematic representation of the the cataclastic fault plane, under the influence of hydrothermal and meteoric fluids and the uplift of the Rhine Graben shoulders development of the minerals in
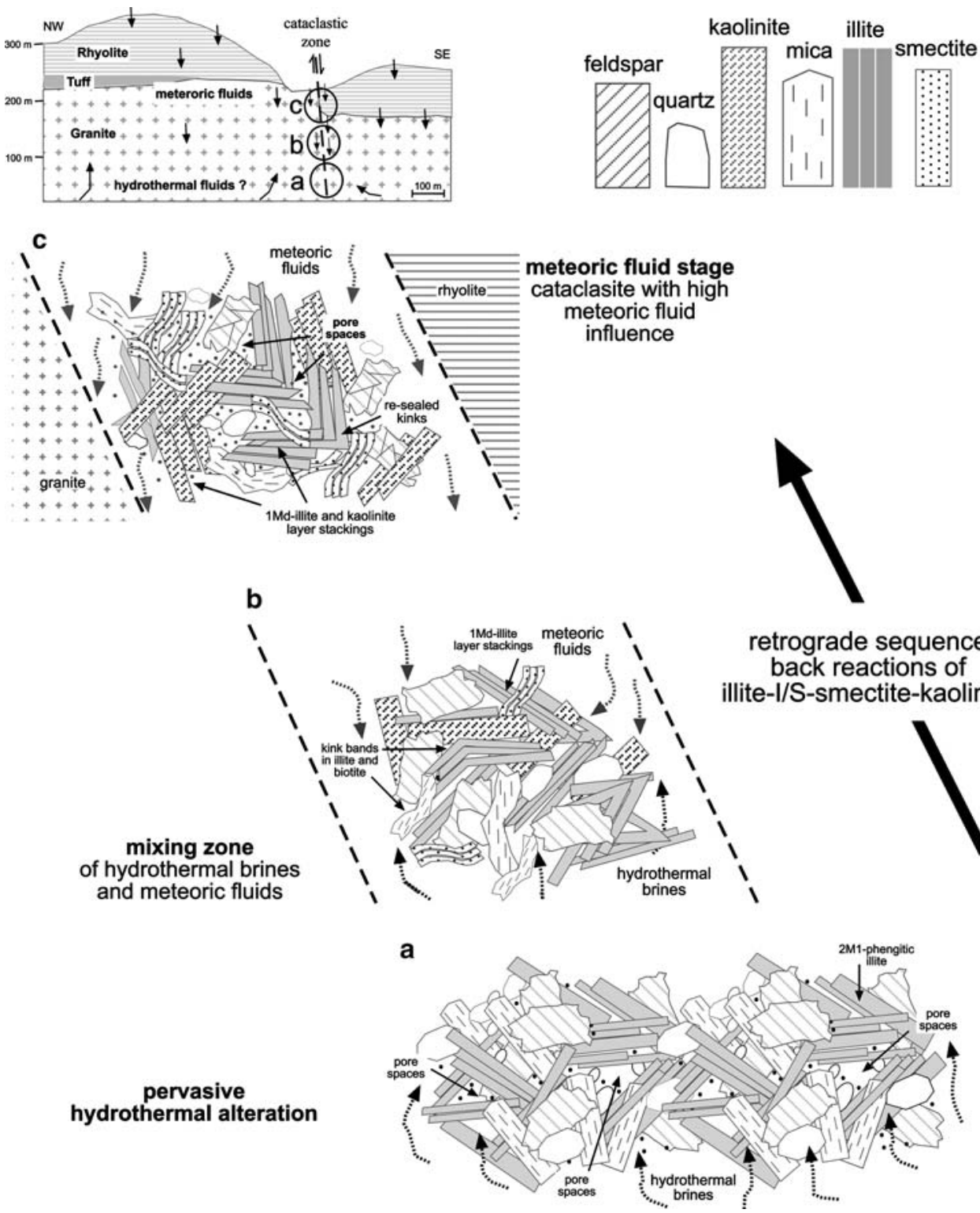

Urach 3). Such fluids are typical of high $p \mathrm{CO}_{2}$ contents, where the lower carbonate content of granitic crystalline rocks give a low buffering capacity, hence yielding neutral to slightly acidic solutions (Appelo and Postma 1999). These fluids differ from the more alkali concentrated brines of the Heidelberg borehole, which result from percolation through young Miocene evaporites (Carlé 1975).

The compositions of the $2 \mathrm{M}_{1}$ Schauenburg illite are also very similar to those described in felsic volcaniclastic rocks of the Kakkonda active geothermal system of Japan by Inoue et al. (2004), where phengitic $\mathrm{Mg}+$ Fe rich R3 illite formed at depths $>750 \mathrm{~m}\left(>174^{\circ} \mathrm{C}\right)$ under the influence of circulating NaCl-rich brines $(\mathrm{pH}$ 7.3), which were considered to represent a mixture of meteoric and fossil seawater that was trapped in the sediments.
Exhumation and flushing of the fault

The fault-related stage of alteration is recognizable in the layer-by-layer transformation from $2 \mathrm{M}_{1}$ illite to $1 \mathrm{M}_{\mathrm{d}}$ (R3) illite-smectite (Figs. 7c, 11b). This reaction was formed by new illite-smectite crystallites that overgrow kinked white mica structures, but are themselves only slightly deformed (Fig. 8a, b). As the fault cuts the Permian rhyolite, and slightly offsets the main $\mathrm{N}-\mathrm{S}$ striking Rhine Graben boundary fault, this stage of alteration is attributed to exhumation and uplift along the fault during Tertiary or post-Tertiary times.

These Al-rich illite-smectite are most predominant within the cataclasite, and have compositions notably depleted in $\mathrm{K}, \mathrm{Mg}$ and $\mathrm{Fe}$. They are similar to some of the illites described by Inoue et al. (2004) formed from near neutral $\mathrm{pH}$ and Na-rich solutions generated by progres- 
sive hydrolytic reactions between felsic glass and groundwater formed at temperatures $>133-160^{\circ} \mathrm{C}$. In the Schauenburg Fault, we attribute these Al-rich illites to cooling hydrothermal basinal brines that were diluted by infiltration of meteoric waters. Such zones of mixing have been documented in the present day chemistry of ground waters along the Rhine Graben margin (Bender 1995; Durst and Vuataz 2000) and have been reported in fluid inclusion studies of diagenetic minerals (Behr et al. 1987).

The significant quantities of kaolinite along the fault, which formed mainly by the replacement of illite-smectite (Fig. 8d), reflects the final stage of fault zone flushing and implies the circulation of large volumes of dilute waters of meteoric origin. The alteration textures observed in the cataclasite are very similar to those documented in granites of Trial Hill in east Queensland by Robertson and Eggleton (1991). The layer-by-layer transformation process involves the replacement of $\mathrm{K}^{+}$ions by $\mathrm{H}_{3} \mathrm{O}^{+}$ ions in the mica interlayer sites and, therefore, involves the release of cations into solution. The reaction of white mica to kaolinite is well documented and is particularly well known from the hydrothermal or supergene alteration of granites (Robertson and Eggleton 1991). Key factors controlling this reaction are low temperatures $<120^{\circ} \mathrm{C}$, large fluid-to-rock ratios and acidic conditions. This stage of alteration was therefore enhanced by the influx of fresh, potentially organic-rich meteoric waters as the fault was exhumed to near surface levels.

Similar alteration was observed along the main eastern boundary fault, during the construction of the train tunnel in Heidelberg (V. Schweizer, personal communications), supporting the interpretation of percolation of these younger waters to be fault-controlled. The enhanced fabrics and permeabilities along these faults allowed a down-flowing fluid movement along older (pre-existing) fractures of the eastern shoulders along the half-graben structure. This stage of fluid flow likely corresponds to the stage of REE and $\mathrm{Pb}$ enrichment within the fault, described by Marbach (2002), and Th-U disequilibrium modeled ages supports a young timing $\left(10^{5}-10^{6}\right.$ years $)$ for this final event.

\section{Conclusions}

A retrograde sequence of fluid-controlled, low temperature clay mineral back-reactions has occurred along the Schauenburg oblique-slip fault of the uplifted eastern shoulder of the Rhine Graben. The initial stage of alteration was marked by the dissolution of plagioclase and $\mathrm{K}$-feldspar under the influence of hot, but mildly acidic Jurassic hydrothermal brines. Alteration to K-illite of phengitic composition is attributed to regional, pervasive fluid-flow, best preserved in the Permian rhyolite. Subsequent cooling and a dilution of waters passing through the fault zone during Tertiary uplift of the rift shoulders, formed successively cation-depleted clays, which produced illite-smectite mixed-layers, pure smectite and finally pure kaolinite. This study identifies the Schauenburg Fault as a primary location for the mixing of basement brines and meteoric waters with fault zone flushing corresponding to uplift and exhumation of the Rhine Graben flanks.

Acknowledgements This study was funded through the GRK 273 "Fluid-rock interaction" grant of the DFG, Germany. The research was also supported by the "Landesgraduiertenförderung" Germany and the US National Science Foundation (EAR0230055). We thank Donald Peacor (Michigan) and Margot Isenbeck-Schröter (Heidelberg) for helpful discussions, and Ulrich Glasmacher for reviewing the paper.

\section{References}

Abad I, Nieto F, Peacor DR, Velilla N (2003) Prograde and retrograde diagenetic and metamorphic evolution in metapelitic rocks of Sierra Espuna (Spain). Clay Miner 38:1-23

Abebe T (2000) Geological limitations of a geothermal system in a continental rift zone: example the Ethiopian rift valley. In: Proceedings World Geothermal Congress, Kyushu-Tohoku, Japan, May 28-June 10

Andrae A, Osann A (1893) Erläuterungen zur Geologie des Blattes Heidelberg. 5. Auflage von Hans Thürach (1995) Mitt Bad Geol L-Anst 2:345-388

Appelo CAJ, Postma D (1999) Geochemistry, groundwater and pollution. Balkema, Rotterdam, p 536

Aquilina L, Pauwels H, Genter A, Fouillac C (1997) Water-rock interaction processes in the Triassic sandstone and the granitic basement of the Rhine Graben: geochemical investigations of a geothermal reservoir. Geochim Cosmochim Acta 61:4281-4295

van Balen RT, Cloetingh SAPL (1993) Stress-induced fluid flow in rifted basins. In: Horbury AD, Robinson AG (eds) Diagenesis and basin development. American Association of Petroleum Geologists, Tulsa, Okalahoma, pp 87-98

Bartels J, Kühn M, Pape H, Clauser C (2000) A new aquifer simulation tool for coupled flow, heat transfer, multi-species transport and chemical water-rock-interaction. In: Proceedings World Geothermal Congress, Kyushu-Tohoku, Japan

Behr H-J, Horn EE, Frentzel-Beyme K, Reutel C (1987) Fluid inclusions characteristics of the Variscan and post-Variscan mineralizing fluids in the FRG. Chem Geol 61:273-285

Bender K (1995) Herkunft und Entstehung der Mineral-und Thermalwässer im nördlichen Schwarzwald. Heidelberger Geowissenschaftliche Abhandlungen: Band 85; Ruprecht-Karls-Universität Heidelberg, p 145

Bove DJ, Eberl DD, McKarty DK, Meeker GP (2002) Characterization and modeling of illite crystal particles and growth mechanisms in a zoned hydrothermal deposit, Lake City, Colorado. Am Mineral 87:1546-1556

Brindley GW, Brown G (eds) (1980) Crystal structures of clay minerals and their X-ray identification. Monograph 5: Mineralogical Society London, p 326

Brockamp O, Clauer N, Zuther M (2003) Authigenic sericite record of a fossil geothermal system: the Offenburg trough, central Black Forest, Germany. Int J Earth Sci 92:843-851

Carlé W (1958) Rezente und fossile Mineral- und Thermalwässer im Oberrheintalgraben und seiner weiteren Umgebung. Jber Mitt Oberrh Geol Ver 40:77-105

Carlé W (1975) Die Mineral- und Thermalwässer von Mitteleuropa. Wissenschaftliche Verlagsgesellschaft mbH, p 643

Clauer N, O' Neil JR, Furlan S (1995) Clay minerals as record of temperature conditions and duration of thermal anomalies in the Paris Basin, France. Clay Miner 30:1-13

Clauser C, Griesshaber E, Neugebauer H (2002) Decoupled thermal and mantle helium anomalies: implications for the transport regime in continental rift zones. J Geophysical Res 107(B11):1-1-1-16 
Dong H, Peacor DR, Freed RL (1997) Phase relations among smectite, R1 illite-smectite and illite. Am Mineral 82:379-391

Durst P, Vuataz FD (2000) Fluid-rock interactions in hot dry rock reservoirs. A review of the HDR sites and detailed investigations of the Soultz-sous-Forets system. In: Proceedings World Geothermal Congress 2000, Kyushu-Tohoku, Japan, May 28June 10

Ehrenberg SN, Aagaard P, Wilson MJ, Fraser AR, Duthie DM (1992) Depth-dependent transformation of kaolinite to dickite in sandstones of the Norwegian continental shelf. The Mineralogical Society, pp 325-352

Evans JP (1990) Textures, deformation mechanisms and the role of fluids in the cataclastic deformation of granitic rocks. In: Knipe RJ, Rutter EH (eds) Deformation mechanisms, rheology and tectonics. Geological Society Special Publication 54:29-39

Frey M (1987) Very low-grade metamorphism of clastic sedimentary rocks. In: Frey M (eds) Low temperature metamorphism. Chapman and Hall, Blackie, pp 9-58

Gautschi A (2000) Hydrogeology of a fractured shale (Opalinus clay): Implications for deep geological disposal of radioactive wastes. Hydrogeol J 9:97-107

Grathoff GH, Moore DM (1996) Illite polytype quantification using WILDFIRE calculated X-ray diffraction patterns. Clays Clay Miner 44:834-842

Hess JC, Lippolt HJ (1996) Numerische Stratigraphie permokarbonischer Vulkanite Zentraleuropas. Geol Jb Hessen III: Odenwald 124:39-46

Hower J, Mowatt TC (1966) The mineralogy of illites and mixedlayer illite/montmorillo-nites. Am Mineral 51:825-854

Hunziker JC, Frey M, Clauer N, Dallmeyer RD, Friedrichsen H, Flehmig W, Hochstrasser K, Roggwiler P, Schwander H (1986) The evolution of illite to muscovite: mineralogical and isotopic data from the Glarus Alps, Switzerland. Contrib Mineral Petrol 92:157-180

Illies JH (1968) Graben tectonics as related to crust-mantle interaction. In: Illies JH, Mueller S (eds) Graben problems. International Upper Mantle Project, Scientific Report 27

Illies JH, Fuchs K (1974) Approaches to taphrogenesis. Inter-Union Commission on Geodynamics Scientific Report 8, Stuttgart

Inoue A, Meunier A, Beaufort D (2004) Illite-smectite mixed-layer minerals in felsic volcaniclastic rocks from drill cores Kakkonda Japan. Clays Clay Miner 52(1):66-84

Kim JW, Peacor DR, Tessier D, Elsass F (1995) A technique for maintaining texture and permanent expansion of smectite interlayers for TEM observations. Clays Clay Miner 43:51-57

Knipe RJ (1993) The influence of fault zone processes and diagenesis on fluid flow. In: Horbury AD, Robinson AG (eds) Diagenesis and basin development. Am Assoc Pet Geol Stud Geol 36:135-148

Lampe C, Person M, Nöth S, Ricken W (2001) Episodic fluid flow within continental rift basins: some insights from field data and mathematical models of the Rhine Graben. Geofluids I:4252

Laubscher H (2001) Plate interactions at the southern end of the Rhine Graben. Tectonophysics 343(1-2):1-19

Lippolt HJ, Kirsch H, Plein E (1990) Karbonische und permische Vulkanite aus dem Untergrund des nördlichen Oberrheingrabens: Art, Altersbestimmung und Konsequenz. Jber Mitt Oberrhein Geol Ver 2:227-242

Marbach T (2002) Fluid-rock interaction history of a faulted rhyolite-granite contact, eastern Rhine Graben Shoulder, SWGermany: alteration processes determined by $\mathrm{Sr}-\mathrm{Pb}$-isotopes, $\mathrm{Th}-\mathrm{U}$-disequilibria and elemental distributions. $\mathrm{PhD}$ thesis, University of Heidelberg, p 140

Marbach T, Kober B, Mangini A, Warr L, Schleicher A (in press) Mobility of U-Th radionuclides connected with fault porosity: a case study of the Schauenburg Fault, Rhine Graben Shoulder, Germany. Phys Chem Earth

May F, Hoernes S, Neugebauer HJ (1996) Genesis and distribution of mineral waters as a consequence of recent lithospheric dynamics: the Rhenish Massif, Central Europe. Geol Rundsch 85:782-799
Moore DM, Reynolds RC (1997) X-ray diffraction and the identification and analysis of clay minerals. Oxford University Press, New York, p 378

Morrow CA, Radney B, Byerlee JD (1984) Permeability of fault gouge under confining pressure and shear stress. J Geophysical Res B 89:3193-3200

Oertel G (1985) The relationship of strain and preferred orientation of phyllosilicates grains in rocks: a review. Tectonophysics 100:413-447

Pauwels H, Fouillac C, Fouillac AM (1993) Chemistry and isotopes of deep geothermal salinge fluids in the Upper Rhine Graben: origin of compounds and water rock interactions. Geochim Cosmochim Acta 57:2737-2749

Peacor DR (1992) Diagenesis and low-grade metamorphism of shales and slates. In: Buseck PR (ed) Minerals and reactions at atomic scale: transmission electron microscopy. Rev Mineral 27:335-380

Person M, Garven G (1994) A sensitivity study of the driving forces on fluid flow during continental-rift basin evolution. Geol Sci Am Bull 106:461-475

van der Pluijm BA, Ho N, Peacor D (1994) High-resolution X-ray texture goniometry. J Struct Geol 16(7):1029-1032

Pribnow D, Clauser C (2000) Heat and fluid flow at the Soultz hot dry rock system in the Rhine Graben. In: Proceedings World Geothermal Congress Kyushu-Tohoku, Japan, May 28-June10

Prodehl C, Mueller St, Haak V (1995) The European Cenozoic rift system: Continental rifts, evolution, structure, tectonics. In: Olsen KH (ed) Developments in Geotectonics 25:133-212

Robertson ID, Eggleton RA (1991) Weathering of granitic muscovite to kaolinite and halloysite and of plagioclase-derived kaolinite to halloysite. Clays Clay Miner 39(2):113-126

Schmidt SM, Casey M (1986) Complete fabric analysis of some commonly observed quartz c-axis patterns. In: Hobbs BE, Heard HC (eds) Mineral, rock deformation: laboratory studies. Am Geophys Un Geophys Monogr 36:263-287

Schumacher ME (2002) Upper Rhine Graben: role of preexisting structures during rift evolution. Tectonics 21(1):6-1-6-17

Sibson RH (1994) Crustal stress, faulting and fluid flow. In: Parnell $\mathbf{J}$ (ed) Geofluids: origin, migration and evolution of fluids in sedimentary basins. Geological Society Special Publication 78:69-84

Solum JG, van der Pluijm BA, Peacor DR, Warr LN (2003) Influence of phyllosilicate mineral assemblages, fabrics, and fluids on the behavior of the Punchbowl Fault, southern California. J Geophys Res 108(B5):5-1-5-12

Srodon J, Eberl D (1984) Illite. In: Baily SW (ed) Micas. Reviews in Mineralogy 13:495-544

Stanislavsky E, Gvirtzman H (1999) Basin-scale migration of continental-rift brines: paleohydrologic modeling of the Dead Sea basin. Geology 27(9):791-794

Stober I, Bucher K (2004) Fluid sinks within the earth's crust. Geofluids 4:143-151

Stober I, Bucher K (2000) Herkunft der Salinität in Tiefenwässern des Grundgebirges unter besonderer Berücksichtigung der Kristallinwässer des Schwarzwaldes. Grundwasser 3(5):125-140

Stober I, Bucher K (1999) Origin of salinity of deep groundwater in crystalline rocks. Terra Nora 11:181-185

Velde B (1965) Experimental determination of muscovite polymorph stabilities. Am Mineral 50:436-449

Velde B (1985) Developments in sedimentology: clay minerals, a physico-chemical explanation of their occurrence. Elsevier, Amsterdam, p 427

Warr LN, Cox S (2001) Clay mineral transformations and weakening mechanisms along the Alpine Fault, New Zealand. Geological Society London, Special Publication 186:85-101

Warr LN, Nieto F (1998) Crystallite thickness and defect density of phyllosilicates in low-temperature metamorphic pelites: a TEM and XRD study of clay-mineral crystallinity-index standards. Can Mineral 36:1453-1474

Warr LN, Rice AHN (1994) Interlaboratory standardization and calibration of clay mineral crystallinity and crystallite size data. J Metamorphic Geol 12:141-152 
Wenk HR (ed) (1985) Preferred orientation in deformed rocks. Academic, Orlando

Wibberley C (1999) Are feldspar-to-mica reactions necessarily reaction-softening processes in fault zones? J Struct Geol 21:1219-1227

Wintsch RP, Christoffersen R, Kronenberg AK (1995) Fluid-rock reaction weakening of fault zones. $\mathbf{J}$ Geophys Res 100(B7):13021-13032
Yoder HS, Eugster HP (1955) Synthetic and natural muscovites. Geochim Cosmochim Acta 8(5-6):225-280

Zhao G, Peacor DR, McDowell SD (1999) Retrograde diagenesis of clay minerals in the Freda Sandstone, Wisconsin. Clays Clay Miner 47:119-130 